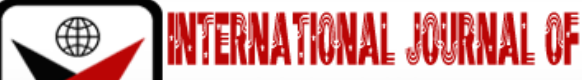

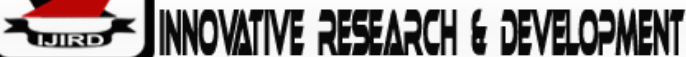

ISSN 2278-0211 (Online)

\section{Influence of Architectural Curricullum on Sustainable Innovative Capability among Architecture Graduates in Nigeria}

Oluwadamilola Ajoke Alabi
Lecturer, Department of Architecture,
Bells University of Technology, Ota, Ogun State, Nigeria
Edikan Michael Okon
Lecturer, Department of Architecture,
Bells University of Technology, Ota, Ogun State, Nigeria
Adewale Segun Alabi
Lecturer, Department of Architecture,
Bells University of Technology, Ota, Ogun State, Nigeria
Abideen Dare Abass
Lecturer, Department of Architecture,
Bells University of Technology, Ota, Ogun State, Nigeria

\begin{abstract}
:
Architectural education originated through the apprenticeship system. This evolved into tertiary education based on designed curriculum. The design of the architecture curriculum for universities in Nigeria, to an extent inspires within graduates the desire to be innovative. Innovative capabilities vary from person to person. Therefore, this study aimed at evaluating the extent to which the architecture curriculum influences the sustainable innovative capability (SIC) of architecture graduates in Nigeria. A hypothesis was raised to test the level of significance of the impact. A quantitative approach was used with data gathered from a sample size of 370 of a population. Simple linear regression was used to analyse the data. An equation of best fit was derived and the null hypothesis was rejected. Findings show that the architecture curriculum has a significant influence on the sustainable innovative capability of architecture graduates in Nigeria. The scope of the curriculum and the provision of practice learning opportunities have the highest positive constants, thus, being the variables that most positively influence SIC. Constant upgrade of the curriculum to keep up with global expectation is recommended to reduce capability failure.
\end{abstract}

Keywords: Construction, Economic growth, Built-environment, Sustainable

\section{Introduction}

Science, technology, and innovation hold the key to linking the three dimensions of sustainability as they have the potential to effectively address the problems inherent in the three dimensions (Lee \& Matthews, 2013). 'Innovation' comes from the art of addressing strategic problems which are to be resolved by finding unique approaches and therefore bringing about the act of carrying out business in value-creating ways which reflect changing social anticipations thereby supporting greater sustainability (Dearing, 2000). Sustainable innovation uses change to meet human needs and values and plays various roles in sustainability transition (Juma \& C, 2005; Dearing, 2000). It sustains economic growth, reduces hunger and poverty, and offers environmentally friendly modes of economic production and consumption (Lee, et al., 2014). Thus, Sustainable Innovative Capability (SIC) yokes economic and social trends together with knowledge and experience to create value and generate enterprise in ways that command respect (Dearing, 2000).

Historically, architectural education has its roots in apprenticeship where a pupil would train under a master for many years before being graced with the title 'Architect'. Architects learned through years of practical experience and under mentorship, which, gave birth to levels of promotion from journeyman to master craftsman. They performed both design and construction and learned through effort, trials, and inaccuracies. They also learned by attaching themselves to various building sites to learn a wide range of crafts thus gaining affirmative experience (Carpenter, 1997). Some renowned architects who received training through this system are Frank Lloyd Wright, Mies Van der Rohe, and Le Corbusier (Langar, 2017). As architectural education evolved, formal procedures were introduced thereby making the need for architecture to be taught at tertiary institutions. Diplomas were initially awarded upon completion of the training. These progressed to Bachelor, Masters, and Doctor of Philosophy certificates. In Nigeria, formal Architectural education started in the late 1940s (Adegbile, 2012; Oluwatayo, 2009). This was in response to the need for Nigerians to learn to design with the underlying understanding of their culture and climate needs. 
The curriculum is distinct from instruction as it suggests the result and not the means of instruction (Johnson Jr, 1967). Marsh, (1997) corroborates this by defining curriculum as a product, content, set of performance objectives, or a combination of experiences and plans which students complete under the guidance of the school. See Figure 1.

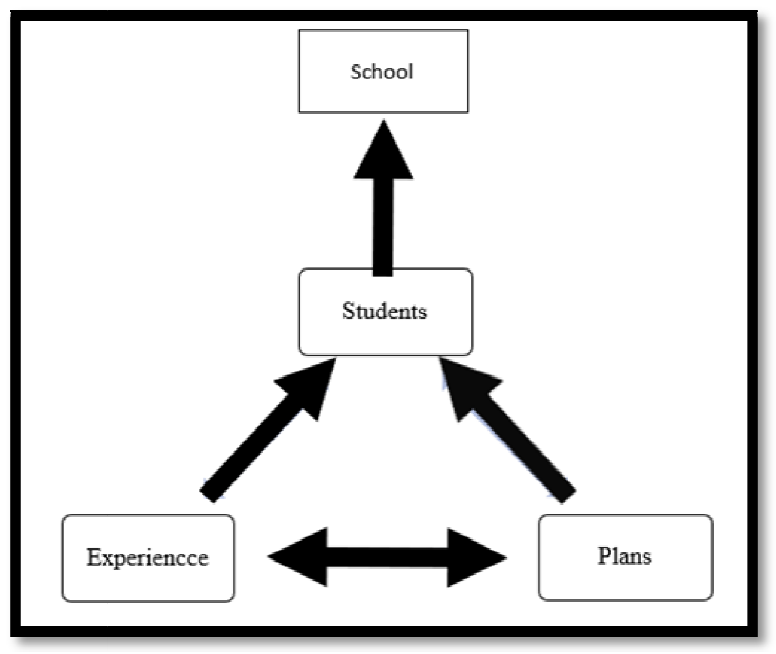

Figure 1: Definition of Curriculum

Source: Adapted from Marsh, 1997; Johnson Jr., 1967

Everyone is born with some level of innovativeness and creativity. However, levels are different and this may be due to various factors. Graduates of architecture institutions appear to be much more explorative and, apart from the professional practice of architecture, diversify into other fields. Their choice of career path may have been influenced by the competitive advantage gained while undergoing architectural training in the tertiary institution. This study, therefore, examines architectural education to determine the influence of the architectural curriculum on the Sustainable Innovative Capability of architecture graduates in Nigeria.

Studies reveal that many countries in Africa are lacking in innovative capabilities leading to capability failure (Lee, 2013). Further studies show that universities are centers through which innovation can be encouraged via programmes that provide competitive advantage (Lynch \& Baines, 2004). Practical and service-based courses, one of which is architectural education, therefore to an extent, can bring about self-awareness and in turn empowerment which helps to address the qualitative dimension of outputs (Aldrich, 2002). However, there is limited research available on the contributions of architectural education to the innovative capabilities of her graduates in Nigeria and this research seeks to fill in this major gap. The identification of the research problem gave birth to the overarching question of what influence does the architectural curriculum have on sustainable innovative capability (SIC) of architecture graduates in Nigeria? To answer this question, a hypothesis was raised as shown:

- $H_{0}=$ the architectural curriculum has no significant influence on SIC of architecture graduates in Nigeria.

- $H_{1}=$ the architectural curriculum has significant influence on SIC of architecture graduates in Nigeria.

\section{Methodology}

The quantitative research method was used to carry out this study using the survey approach. A sample of 370 respondents from a finite population of 10,131 architects of different categories captured in the 2018 register of the Nigerian Institute of Architects (NIA) was selected and administered questionnaires. Random selection was favoured for picking the respondents and the questionnaires were analysed using descriptive analysis to assess the characteristics of the respondents. Linear regression analysis was then used to determine the hypothesis which would be accepted.

\section{Findings}

\subsection{Characteristics of Architecture Graduates in Nigeria}

The majority of architects in Nigeria are male. Figure 2 reveals that female architects make up $20 \%$ while men are $80 \%$ of the respondents. Thus, proving that the architecture profession is male-dominated, similar to other professional careers (Anthony, 2016). 


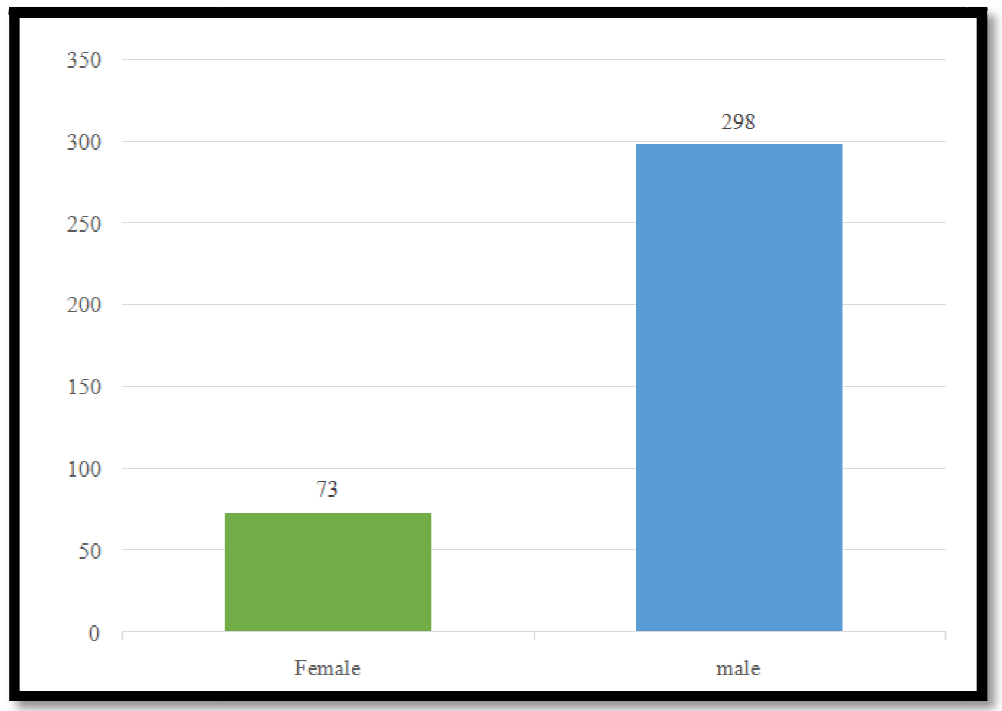

Figure 2: Gender Characteristics of Respondents Source: Field Survey, 2019

The respondents were mostly Postgraduate Masters' certificate holders (73\%) as seen in Figure 3. Ph.D. degree holders account for $14 \%$ while those with Bachelor's degree and HND as their highest qualification are $7 \%$ each. This implies that most architects in Nigeria have advanced education.

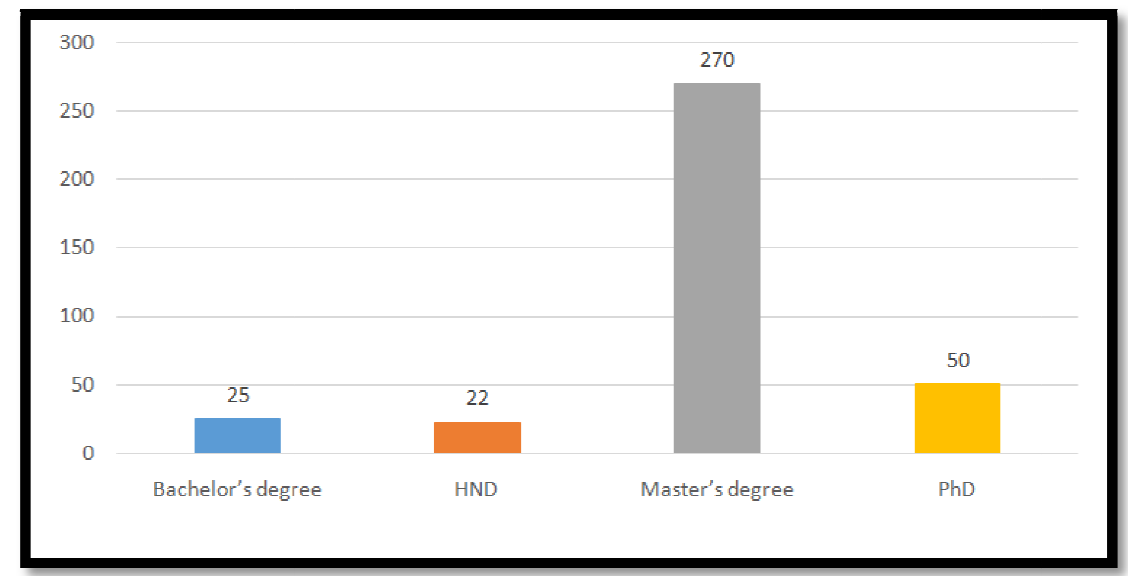

Figure 3: Highest Level of Respondents' Educational Attainment in Architecture Source: Field Survey, 2019

Figure 4 shows the geographical distribution of architecture graduates surveyed in Nigeria. The largest percentage of architecture graduates (40\%) are resident in the South West followed by $20 \%$ in North Central, $15 \%$ in South-South, 10\% in South East, 9\% in North West 9\%, and 6\% in North East. The South West and North Central geopolitical zones in Nigeria also have the highest concentrations of schools of architecture, urban development, and commercial activities.

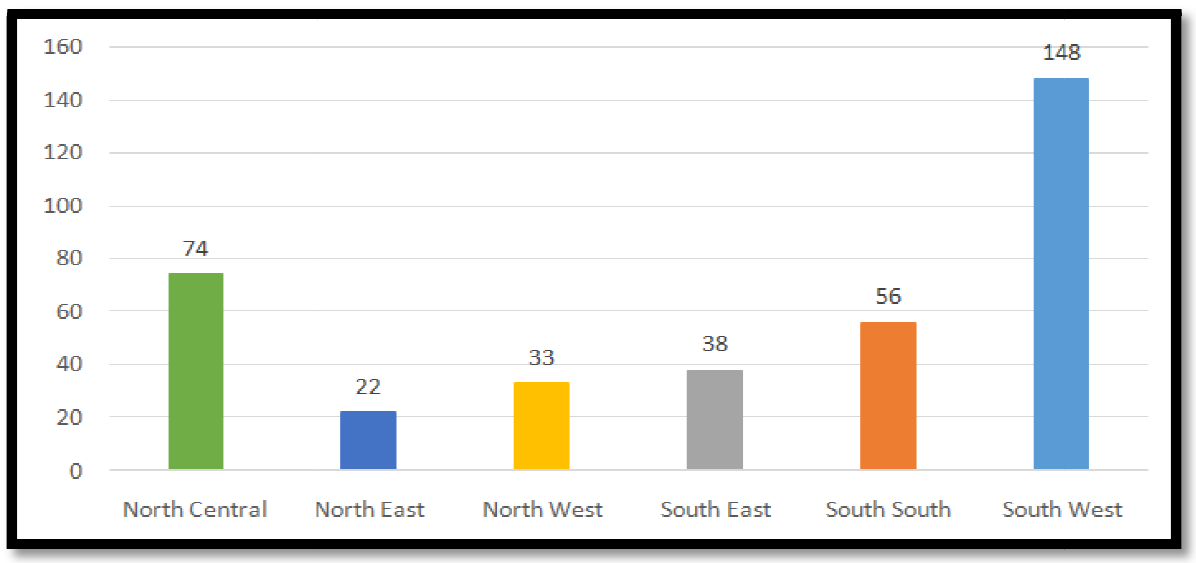

Figure 4: Count of Geo-Political Zone Source: Field Survey, 2019 
$34 \%$ of the respondents are employed and also engage in an alternative innovative private business. $44 \%$ are selfemployed in professional practice and have an alternative innovative/creative business while $22 \%$ are employees. Figure 5 graphically presents this. This shows that most architecture graduates in Nigeria have a source of income that is not dependent on an employer's wage.

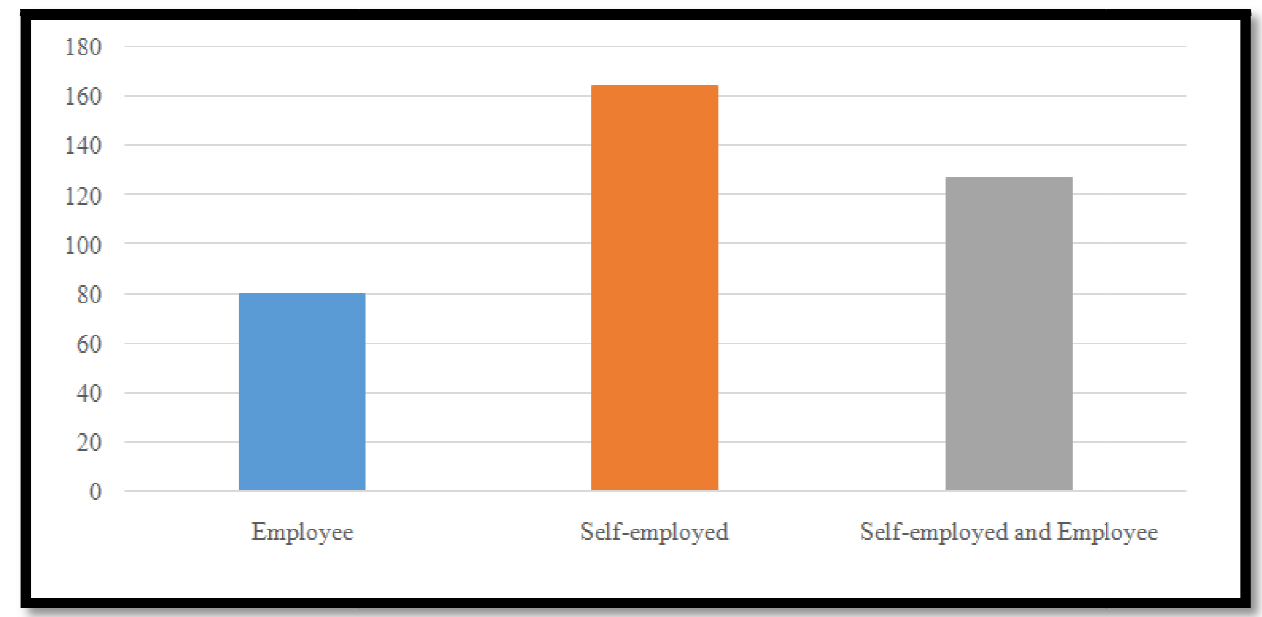

Figure 5: Respondents' Employment Status Source: Field Survey, 2019

Self-employed respondents own architectural consultancies (40\%), construction firms (31\%), consortiums (16\%), design \& build companies (9\%), education/research institutes (2\%), interior \& exterior design firms (1\%) and real estate firms (1\%) showing that architecture graduates mostly practice within their trained profession. Figure 6 summarises this finding.

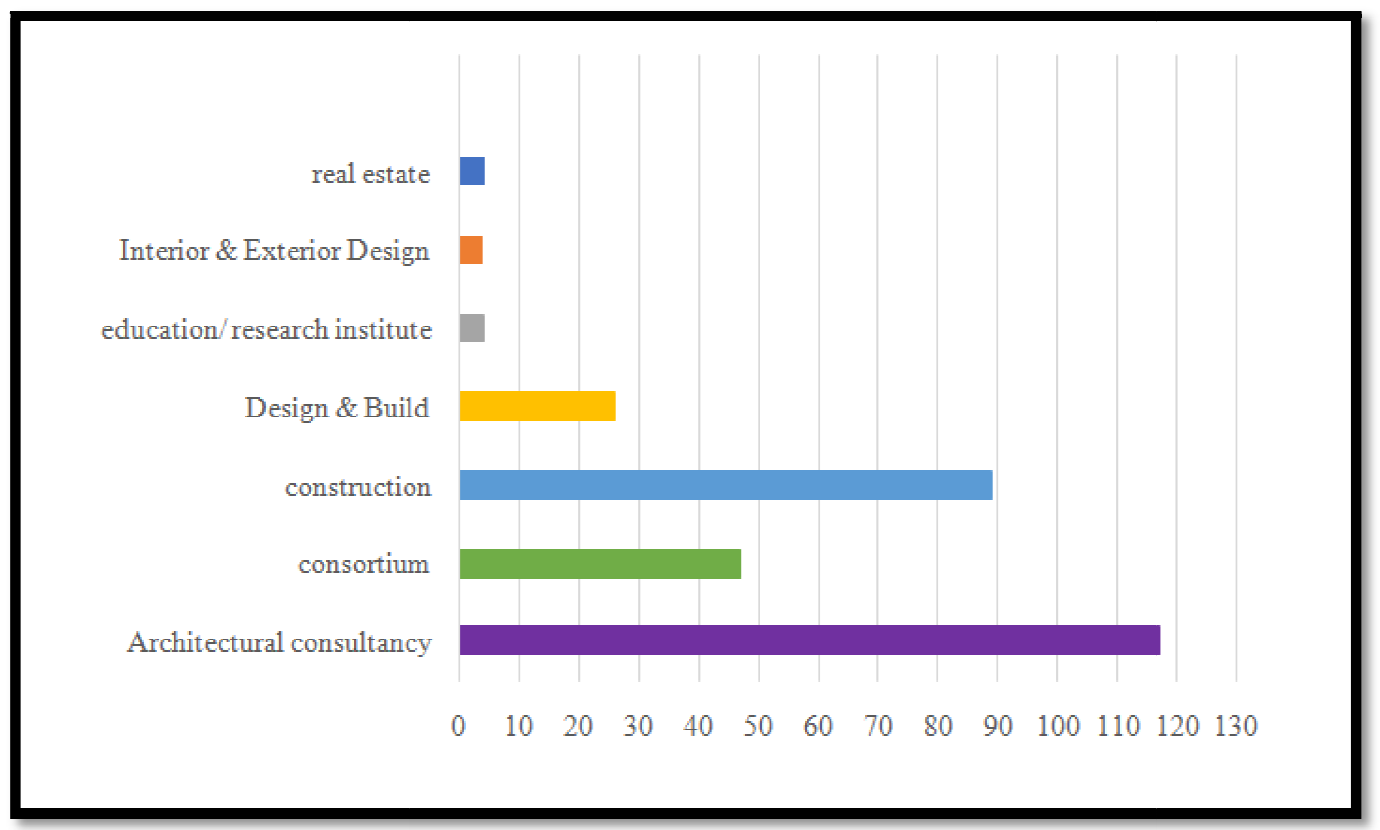

Figure 6: Main Business of Self-Employed Respondents Source: Field Survey, (019)

Self-employed graduates of architecture were found to be involved in various innovative businesses that act as a stream of wealth. The innovations ranged from art to farming, and 3D rendering to motivational speaking. However, 3D rendering/graphics held the highest percentage at 14\%. Real estate had $9 \%$, Interior design $7 \%$, 5\% diversified into arbitration, $4 \%$ went into landscaping and furniture design respectively. This reveals that when architecture graduates exhibit innovative diversification, quite a number diversify into skills that support the practice of architecture. 


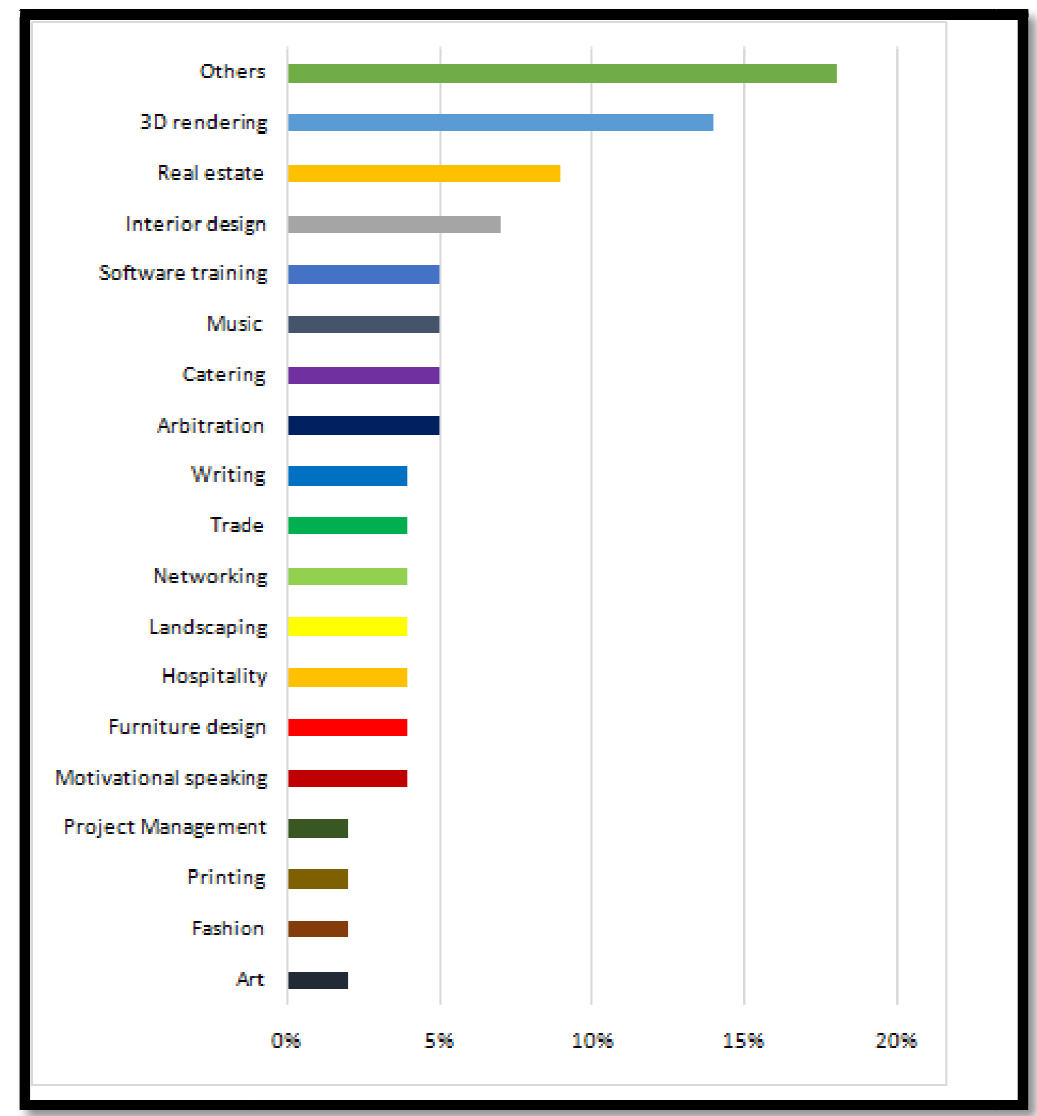

Figure 7: Innovative/Creative Business of Self-Employed Respondents Source: Field Survey, 2019

\subsection{Influence of Architectural Curriculum on Innovative Capability}

Ten variables describe the architecture curriculum of tertiary institutions in Nigeria. These variables show significant contribution to the explanation of the residual variation in the dependent variable. See Table 1.

\begin{tabular}{|c|c|c|}
\hline S/N & NAME & CODE \\
\hline & (Constant) & \\
\hline 1 & Vision of the curriculum & VISIO \\
\hline 2 & Philosophy of the curriculum & PHILO \\
\hline 3 & Context of the curriculum & CONTE \\
\hline 4 & Scope of the curriculum & SCOPE \\
\hline 5 & Depth/rigour of the curriculum & DEPTH \\
\hline 6 & Relevance of the curriculum & RELEV \\
\hline 7 & Focus/direction of the curriculum & FOCUS \\
\hline 8 & Flexibility of the curriculum & FLEXI \\
\hline 9 & Timeliness of the curriculum & TIMEL \\
\hline 10 & Exposure to practice learning opportunities & EXPOS \\
\hline & Sustainable Innovative Capability (Dependent variable) & SIC \\
\hline
\end{tabular}

Table 1: Specification of Variables

Source: Field Survey, 2019

The least square algorithms applied to the model.

SIC $=\beta_{0}-\beta_{1}$ VISIO $+\beta_{2}$ PHILO $+\beta_{3}$ CONTE $+\beta_{4}$ SCOPE $+\beta_{5}$ DEPTH $-\beta_{6}$ RELEV $+\beta_{7}$ FOCUS $-\beta_{8}$ FLEXI $+\beta_{9}$ TIMEL $+\beta_{10}$ EXPOS $+\varepsilon$

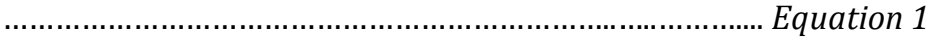

SIC $=1.358-0.370$ VISIO + 0.175PHILO + 0.221CONTE + 0.581SCOPE + 0.150DEPTH - 0.873RELEV + 0.425FOCUS 0.198 FLEXI + 0.310TIMEL + 0.269EXPOS + 0.263 Equation 2

The test carried out checked the influence of the attributes of the architectural curriculum on Sustainable Innovative Capability (SIC) among architecture graduates in Nigeria. R2 at 0.429 showed that $42.9 \%$ of variance in SIC is explained by the architectural curriculum used to train the architects. The remaining $57.1 \%$ is explained by other factors which have not been included in the model. The regression model significantly predicts the dependent variable with the adjusted R2 at 0.413, (Adjusted R -square is not applicable here because it is used to compare models) the F-test is 26.956 at 359 degree of significance and a P-value of 0.000 which is less than the limit of 0.05 . There is therefore enough evidence 
to reject the null hypothesis and accept that there is a relationship between architecture curriculum and SIC of architecture graduates in Nigeria. Hence, the alternate hypothesis was accepted.

As shown in Equation 2, when all other variables are held constant in the model, the vision of the curriculum (VISIO) and relevance of the curriculum (RELEV) each have negative effects on SIC with a constant value of - 0.370 and 0.873 respectively. The flexibility of the curriculum (FLEXI) is also characterized by a negative constant value of -0.198 .

The philosophy of the curriculum (PHILO) has a positive value of 0.172 and this shows that it has a positive impact on SIC. Likewise, the context of the curriculum (CONTE) has a positive effect with a value of 0.221 . The scope of the curriculum (SCOPE) has the highest positive value of 0.581. The depth/rigor of the curriculum (DEPTH) has the smallest positive value of 0.150 . The focus/direction of the curriculum (FOCUS) has a constant value of 0.425 making it the secondhighest attribute that positively influences SIC. Timeliness of the curriculum (TIMEL) is valued at 0.280. Exposure to practice and learning opportunities (EXPOS) has a positive impact on SIC at a positive constant value of 0.320 .

This implies that the philosophical stance through which a curriculum is designed and delivered can affect the direction of thought of students towards a desire for innovativeness. Likewise, the context in which the curriculum is created. The scope, depth, and rigour of the curriculum open students to a broader scheme-of-things thus opening their minds to the possibilities of diversifications that can be achieved through the various courses under study. Practice and learning opportunities provided in the architectural curriculum are field trips, workshop practicals, Work Experience Programmes, internship, participation in conferences among others. These go a long way towards positively influencing architecture graduates to explore their innovative capabilities.

\section{Conclusion}

The research found that the architecture curriculum had a significant impact on the sustainable innovative capability of architecture graduates in Nigeria. This means that the content of the curriculum to which architects are exposed, significantly affects their desire and choice of diversification and how well this innovative capability will be sustained. To further emphasise, the equation derived showed that the relevance, scope, and timeliness of the curriculum had the highest impact.

There is a need to keep the curriculum content constantly up to date with global expectations to encourage innovative capabilities that would keep with the times and not be outdated. For example, this 21 st century has placed a huge emphasis on sustainability concepts and technological advancement. Therefore, the architecture curriculum designed for schools of architecture in Nigeria should be modified to have content relevant to the demands of the 21 st century.

\section{References}

i. Adegbile, M. B. O., (2012). Integrating Sustainability in the Nigerian Architectural Education. Scottish Journal of Arts, Social Sciences and Scientific Studies, pp. 3-14.

ii. Aldrich, T., (2002). Self-awareness and Empowerment in Architectural Education, Plymouth: University of Plymouth.

iii. Anthony, K. H., (2016). Gender Issues in Architecture. In: M. Kanaani\& D. Kopec, eds. The Routledge Companion for Architecture Design and Practice - Established and Emerging Trends. New York and London: Taylor and Francis Group, pp. 533-548.

iv. Carpenter, W. J., (1997). Learning by Building: Design and Construction in Architecture Education. 1st ed. New York: Van Nostrand Reinhold.

v. Dearing, A., (2000). Sustainable Innovation: Drivers and Barriers. Geneva, OEDC TIP Workshop.

vi. Johnson Jr, M., (1967). Definitions and Models in Curriculum Theory. Educational Theory, 7(2), pp. 127-140.

vii. Juma, C. \& C, L. Y., (2005). Innovation: Applying Knowledge in Development. London: Earthscan.

viii. Langar, S. Z., (2017). Incredibly Famous Architects who didn't possess an Architecture Degree. [Online] Available at: https://www.archdaily.com [Accessed 10 January 2019].

ix. Lee, K., (2013). Capability Failure and Industrial Policy to move beyond the Middle-Income Trap: From TradeBased to Technology Based Specialization. In: J. Lin \& J. Stiglitz, eds. Industrial Policy Revolution. London: PalmgraveMacmillian.

x. Lee, K., Juma, C. \& Matthews, J., (2014). Innovation Capabilities for Sustainable Development in Africa - WIDER Working Paper 2014/062, Helsinski, Finland: World Institute for Development Economics Research.

xi. Lee, K. \& Matthews, J., (2013). STI for Sustainable Development, UN.

xii. Lynch, R. \& Baines, P., (2004). Strategy Development in UK Higher Education: Towards Resource-Based Competitive Advantages. Journal of Higher Education Policy and Management, 26(2), pp. 171-187.

xiii. Marsh, C. J., (1997). Perspectives: Key Concepts for Understanding Curriculum. 1st ed. London, Washington: Falmer Press.

xiv. Oluwatayo, A., (2009). A critical Study of the Practice Characteristics of Architectural Firms in Nigeria. Ota: Covenant University. 